\title{
VARIATION IN SHAPE, WEIGHT AND NUMBER OF COTYLEDONS OF PLACENTAE IN KOSI REGION OF BIHAR, NORTH EAST INDIA
}

\author{
M. Yousuf Sarwar'1, Tarannum Yasmin², S. K. Sinha ${ }^{3}$
}

${ }_{1}^{1}$ Associate Professor, Department of Anatomy, Katihar Medical College, Katihar, Bihar, India.

2Professor, Department of Microbiology, Katihar Medical College, Katihar, Bihar, India.

3 Professor, Department of Anatomy, Katihar Medical College, Katihar, Bihar, India.

\begin{abstract}
\section{BACKGROUND}

Placenta serves the most basic metabolic needs of foetus including respiration, nourishment and excretion. It forms an organ for interchange of material between foetus and maternal blood stream without mixing or physical contact of two blood streams. The formation of placenta is a biological event, which is important both embryologically and immunologically. Placenta is a choriodecidual structure which develops during pregnancy and lies implanted on the uterine wall near the fundus. It is connected to the foetus through the umbilical cord. A maternal surface is dull red in colour and is divided by septa into number of irregular quadrilateral lobes termed cotyledons. These septa consist of fibrous tissue with sparse vessels confined to their bases. Placental shape, weight and number of cotyledons varied in different population. It can determine the extent of the health of new born. The placenta produces hormones that play a role in maintaining pregnancy.

The objectives of this study were to compare placental shape, measuring weight and to count the number of cotyledons in each placenta and to have a better concept about maternal well-being and infant health which helps in reducing.
\end{abstract}

\section{MATERIALS AND METHODS}

Fresh, intact 150 placentae were collected from labour room of Katihar Medical College and Hospital during a period of two years in Kosi region of Bihar, North East India. The study was done in Anatomy Department of Katihar Medical College by observation, dissection and weight measuring methods. Photographs of placentae obtained from full term deliveries (normal/Caesarean section) were taken. After proper washing with distilled water, removal of blood clots was done with digital pressure applied over arteries and veins and later on irrigation was done. Shape, weight and no. of cotyledons of placentae were observed and recorded.

\section{RESULTS}

After proper cleaning and dissection, a total of 150 placentas were examined in the present work. Variation in placental shape, weight and no. of cotyledons were found, noted and photographs taken. The main aim of this study was to find variation in morphology in pregnancy especially shape, weight and no. of cotyledons of placenta.

\section{CONCLUSION}

The study was undertaken on placenta obtained from Department of OBG, KMC, Katihar. A total of 150 placentae were examined in Anatomy Dept., KMC. The present study showed most of the placentae were round, oval or irregularly circular. Maximum number of placentae, $46 \%$ was round with periphery thinner than centre. Most of the placentae had weight range between $300-600$ gm. Maximum was $760 \mathrm{gm}$ and minimum was $240 \mathrm{gm}$. Number of cotyledons on maternal surface varied between 11 - 20 . Maximum number of cotyledons was 30 and minimum was 6 . The studies of placentae give the information of prenatal exposure of infant.

\section{KEY WORDS}

Placentae, Shape, Cotyledons, Placental Weight, Variation.

HOW TO CITE THIS ARTICLE: Sarwar MY, Yasmin T, Sinha SK. Variation in shape, weight and number of cotyledons of placentae in Kosi region of Bihar, North East India. J. Evolution Med. Dent. Sci. 2018;7(27):3134-3137, DOI: 10.14260/jemds/2018/704

\section{BACKGROUND}

The placenta is an organ that connects the developing foetus to the uterine wall to allow nutrient uptakes, waste elimination and gaseous exchange via mother's blood supply. Placenta is the most vital organ, because it takes major part in diffusion of various substances between foetus and mother.

'Financial or Other Competing Interest': None.

Submission 28-05-2018, Peer Review 21-06-2018,

Acceptance 27-06-2018, Published 02-07-2018.

Corresponding Author:

Dr. Tarannum Yasmin,

Department of Microbiology,

Katihar Medical College,

Katihar-854105, Bihar, India.

E-mail:drtyasmin@gmail.com

DOI: $10.14260 /$ jemds $/ 2018 / 704$

\section{(c) $($ ) $९$}

Besides secreting hormones, the placenta protects the foetus from immune attack by the mother and induces increased maternal blood flow. Near the time of delivery, the placenta produces hormone that mature the foetal organs in preparation for life outside the uterus. The placenta has a foetal portion formed by chorion frondosum of trophoblast derived from the developing embryo. The maternal portion formed by deciduous basalis derived from the modification of uterine lining of mother.(1) The placenta uses about $1 / 3^{\text {rd }}$ of all the oxygen and glucose supplied to the maternal blood and rate of protein synthesis is higher in the placenta than the liver.(2) The ratio between placenta and new born weight has been reported 1: 6.(3) The placenta is the most accurate record of the infant's prenatal existence.(4) Maternal surface is divided into cotyledons with irregular grooves in between. The foetal surface is smooth, shiny, translucent and covered with amniotic membrane.(5)

Placenta undergoes various changes in its weight, surface area, structure, shape and function continuously throughout 
the gestation to support the growth of foetus in utero. Abnormality in the placenta results in low birth weight, intrauterine growth restriction and still birth which lead to increased rate of perinatal morbidity and mortality.(6) Total no. of cotyledons remains same throughout the gestation. On close inspection, it is being seen to be covered with a thin greyish mottled membrane that represents the shed portion of deciduous basalis. In part this is incomplete exposing the dark red spongy tissue beneath and often it feels gritty to touch due to presence of minute areas of calcification. In some instances areas of calcification are large enough to be visible on $\mathrm{x}$-ray or naked eye, which is usually near the centre of placenta.(7) According to Sprit and colleagues (1982), by 33 weeks more than half of the placentae have some degree of calcification which increases till term. ${ }^{(8)}$

The expelled placenta is a flattened discoidal mass with an approximately circular or oval outline. It has an average volume of $500 \mathrm{~mL}$ (Range 200 - $950 \mathrm{~mL}$ ), an average weight of $470 \mathrm{gm}$ (Range $200-800 \mathrm{gm}$ ), an average diameter of 185 $\mathrm{mm}$ (Range $150-200 \mathrm{~mm}$ ), an average thickness of $23 \mathrm{~mm}$ (Range $10-40 \mathrm{~mm}$ ) and an average surface area of 30000 $\mathrm{mm}^{2}$. Thickest at its centre and rapidly thin towards its periphery where it continues as the chorion leave. ${ }^{(9)}$

The placenta is usually regarded as a foetal organ. It is a vital organ for maintaining pregnancy and promoting normal foetal development. It represents the cooperation of two distinct individuals to form single structure that protects one and enables the genes of the other to live on.(10)

Placental shape, weight and number of cotyledon vary in different population, inspection and observation of it is important for anatomist, embryologist and medical professionals. In our current study work done on the shape, weight and no cotyledons of placenta in human beings in Kosi region of Bihar.

\section{MATERIALS AND METHODS}

The present study was done on placentae, in which samples were collected throughout the study. The study was done on 150 placentae which were collected immediately after delivery, either normal or caesarean section during a period of 2 years from labour room of Katihar Medical College and Hospital and work done in Anatomy Department, KMC, Katihar, Bihar in population of Kosi region of Bihar, a part of North East India. The placentae with attached membrane were collected in buckets covered with lid full of fresh distilled water. Removal of blood clots was done with slight digital pressure over vessel and placentae were washed in distilled water. The cord was cut $6 \mathrm{~cm}$ from its attachment to placenta and membrane was removed. Examination of placenta especially shape, measuring placental weight and observation of number of cotyledons of placenta was carried out and photographed by digital camera. Morphological parameters were measured as follows: - Placental weight was measured by sensitive balance, placenta shape was measured by observation and number of cotyledons was measured by inspection.

\section{RESULTS}

Various observations on gross appearance of human placentae were recorded and analysed. The study was undertaken on the fresh placenta obtained from Department of OBG, Katihar Medical College, in collaboration with Anatomy Department in Kosi region of Bihar, North East India. The study was limited to the placentae obtained from full-term deliveries either normal or caesarean section. A total of 150 placentae were examined in Anatomy Department, KMC, Katihar. The study was grouped under following headings:- Shape, weight and number of cotyledons of placenta.

Table I- Shape of placenta showed marked variations. Majority of them are round, oval or irregularly circular. Maximum no. of placenta $46 \%$ was round with periphery thinner than centre, only $10 \%$ have abnormal shapes like bilobed, trilobed, triangular heart and kidney shaped.

Table II- In present study, most of the placentae weight ranged between 300 - 600 gms. 36\% had 400 - 499 gms, 20\% had 300 - 399 gms. Maximum weight was 760 gms and minimum weight was 240 gms with means of 467.80 gms. Standard deviation of 116.25 gms and standard error of 9.49 gms.

Table III- Number of cotyledons on maternal surface usually varied between $11-20,46 \%$ had $11-15$ and $36 \%$ had $16-20$. Maximum number of cotyledons was 30 and minimum was 6 with mean of 15.81, standard deviation of 4.71 and standard error of 0.38 .

\begin{tabular}{|c|c|c|c|}
\hline $\begin{array}{c}\text { Sl. } \\
\text { No. }\end{array}$ & Shape & $\begin{array}{c}\text { Number of } \\
\text { Placentae }\end{array}$ & Percentage \\
\hline 1 & $\begin{array}{c}\text { Round with periphery } \\
\text { thinner than centre }\end{array}$ & 69 & 46.0 \\
\hline 2 & $\begin{array}{c}\text { Round with periphery } \\
\text { thicker than centre }\end{array}$ & 03 & 02.0 \\
\hline 3 & Oval & 27 & 18.0 \\
\hline 4 & Irregular circular & 33 & 22.0 \\
\hline 5 & Bilobed and Trilobed & 03 & 02.0 \\
\hline 6 & Accessary lobe & 03 & 02.0 \\
\hline 7 & Kidney shaped & 03 & 02.0 \\
\hline 8 & Heart shaped & 03 & 02.0 \\
\hline 9 & Triangular & 06 & 04.0 \\
\hline
\end{tabular}

Table 1. Showing the variation in Shape of Placentae with their Number and Percentage

\begin{tabular}{|c|c|c|c|c|c|}
\hline $\begin{array}{c}\text { Sl. } \\
\text { No. }\end{array}$ & $\begin{array}{c}\text { Weight of } \\
\text { Group (gm) }\end{array}$ & \multicolumn{3}{|c|}{ Number of Placenta } & Percentage \\
\hline & & & Male & Female & \\
\hline 1 & $200-299$ & 12 & 05 & 07 & 08.0 \\
\hline 2 & $300-399$ & 30 & 10 & 20 & 20.0 \\
\hline 3 & $400-499$ & 54 & 22 & 32 & 36.0 \\
\hline 4 & $500-599$ & 39 & 26 & 13 & 26.0 \\
\hline 5 & $600-699$ & 09 & 05 & 04 & 06.0 \\
\hline 6 & $700-799$ & 06 & 04 & 02 & 04.0 \\
\hline
\end{tabular}

Table 2. Showing variation in Weight of Placenta (in gm)

\begin{tabular}{|c|c|}
\hline Range & \\
\hline Minimum weight & - $240 \mathrm{gm}$ \\
\hline Maximum weight & - $760 \mathrm{gm}$ \\
\hline Mean weight & - $\quad 467.80 \mathrm{gm}$ \\
\hline \pm S.D. & - $\quad 116.25 \mathrm{gm}$ \\
\hline \pm S.E. & - $\quad 9.49 \mathrm{gm}$ \\
\hline
\end{tabular}




\begin{tabular}{|c|c|c|c|}
\hline $\begin{array}{c}\text { Sl. } \\
\text { No. }\end{array}$ & $\begin{array}{c}\text { Group of No. } \\
\text { Cotyledons }\end{array}$ & $\begin{array}{c}\text { Number of } \\
\text { Placenta }\end{array}$ & Percentage \\
\hline 1 & $06-10$ & 12 & 08.0 \\
\hline 2 & $11-15$ & 69 & 46.0 \\
\hline 3 & $16-20$ & 54 & 36.0 \\
\hline 4 & $21-25$ & 09 & 06.0 \\
\hline 5 & $26-30$ & 06 & 04.0 \\
\hline \multicolumn{3}{|c|}{ Table 3. Showing variation in Number of Cotyledons } \\
\hline
\end{tabular}

\section{Range}

Minimum No. of Cotyledons - $\quad 06$

Maximum No. of Cotyledons - 30

Mean No. of Cotyledons $\quad$ - 15.81

\pm S.D. $\quad-4.71$

\pm S.E. $\quad-0.38$

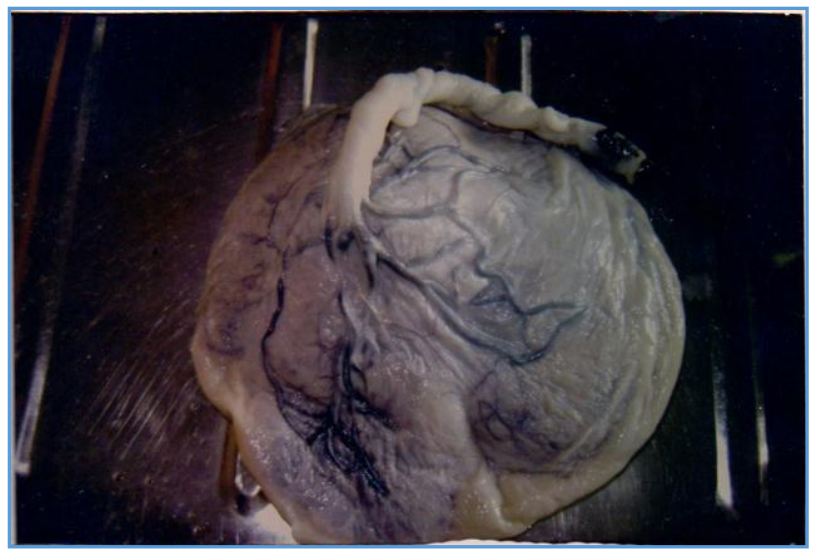

Circular Placenta with Central Attachment of Umbilical Cord

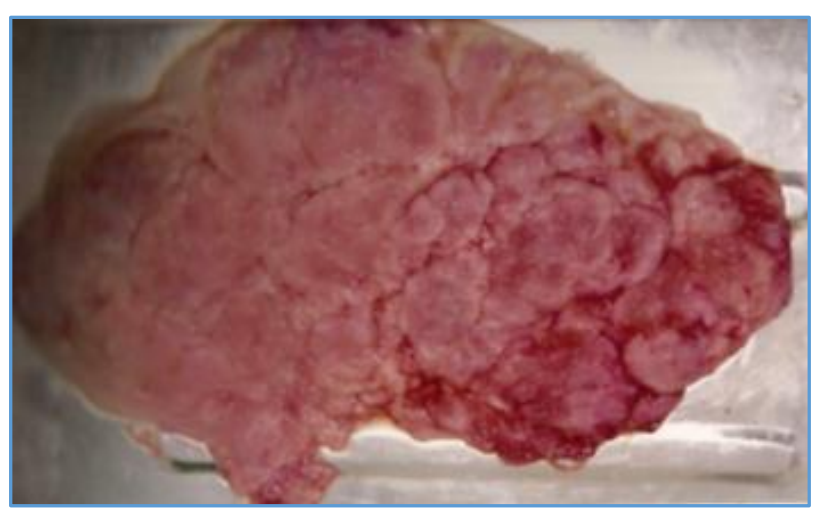

Maternal Surface of Placenta showing Cotyledons

\section{DISCUSSION}

This research studies the overall shape, weight and number of cotyledons of placenta without taking into account any disease or aliments to the mother and foetus developed. The study only concerned with the external form of placenta. Most previous studies focused on studying the change occur to the placenta that result from external factor, but this research was only interested in studying the overall shape, weight and no cotyledon of placenta in Kosi region of Bihar, North East India.

AK Dutta reported that placental growth occurs till 37 weeks. In early part of pregnancy, about 800 to 1000 stem villi radiate from entire chorionic villi. Later with regression of chorionic leave only 60 stem villi persists in human placenta. Maternal cotyledons are 15 to 30 and each cotyledon receives 2 to 3 stem villi.(11) The foetal growth capacity is determined by placental weight. Placental weight and foetal weight will increase proportionately with the progress of pregnancy.(12) Placenta responds to exogenous insults and tries to adapt for varying nutritional level of the mother. If this response of placenta fails to maintain foetal growth, then it results in intrauterine growth retarded babies or various congenital defects.(13) The placenta therefore serves as the major link between the mother and her unborn baby, the foetus. Owing to the delicate and important nature of the placenta, it is sometimes referred to as the mirror of the perinatal period.(14) Jaya et al reported that the average weight of placentae of full-term normal babies was $502.4 \mathrm{gm}$ (SD 43.3) and studied the relationship between placental weight and birth weight and reported that the average weight of placenta of full-term normal babies was 502.4 gm (SD 43.3).(15) The placental weight increased with the increase in birth weight and gestational age.(16) Frisancho et al said that the mean of placenta was $551 \mathrm{gm}$ and the mean of new born infant was $3111.3 \mathrm{~kg} .{ }^{(17)}$

According to Moore and Persaud in 1996, the shape of persistent area of chorionic villi determine the shape of placenta and usually it is a circular area giving discoid shape to the placenta.(18) According to Bhatnagar et al in 1983, the number of maternal cotyledons was 15 - 20.(19) Majumdar et al found that the mean birth weight of babies were $2.8 \pm 0.32$ $\mathrm{kg}$. The mean weight of placenta was $48.85 \pm 47.31 \mathrm{gm}$ and the mean of cotyledon no. of placenta was $17 \pm 2$.(20) According to Gray's Anatomy (2005), the number of maternal cotyledons is $15-30$.

In the present study, shape of placenta showed marked variation. Majority of them were round, oval or irregularly circular. Maximum number of placenta, $46 \%$ was round with periphery thinner than centre. Only $10 \%$ have abnormal shapes like bilobed, trilobed, triangular, heart and kidney shaped. Most of placentae weight ranged between $300-600$ gm. Maximum weight was $760 \mathrm{gm}$ and minimum was $240 \mathrm{gm}$ with mean of $467.80 \mathrm{gm}$. On maternal surface, number of cotyledons varied between 11 - 20. Maximum number of cotyledons was 30 and minimum was 6 with mean of 15.81 . In the present study, we found that the cotyledons number was approximately equal in both sexes of babies. There was a significance between infant weight and placental weight. These studies agree with other studies reported by Manop et al.

\section{CONCLUSION}

The study of placenta suggests the intrauterine status of the foetus. Post-delivery examination of placenta should be done to define the condition of the baby.

The morphological parameters were observed and measured in 150 placentas of normal pregnancies. The placentae were collected from patients delivered at Katihar Medical College, Katihar in Kosi region of Bihar, a part of North East India. The present study includes the observation of shape, measurement of weight and counting the number of cotyledons of placenta. Our present observation shows maximum no. of placenta, $46 \%$ was round with periphery thinner than centre. Maximum weight of placenta was 760 gm and minimum was $240 \mathrm{gm}$ with mean of $467.80 \mathrm{gm}$. Maximum no. of cotyledons on maternal surface was 30 and minimum was 6 with mean of 15.81. Several studies on 
placentae have done before; in spite of that, we feel that our study will be useful to Anatomists, Paediatricians, Gynaecologists and Surgeons of Kosi region of Bihar, North East India in particular and other regions in general.

\section{REFERENCES}

[1] Yetter JF. Examination of the placenta. American Academy of Family Physicians 1998;57(5):1045-54.

[2] Kaplan LG. Forensic aspect of the placenta. Prospect of Paediatric Pathology 1995;19:20-42.

[3] Cunningham FG, Leveno KJ, Bloom SL, et al. Williams Obstetric. Implantation, embryogenesis and placental development. 22 ${ }^{\text {nd }}$ edn. New York: McGraw Hill 2005: p. 39-90.

[4] Benirshke K. The placenta. How to examine it and what you can learn? Contempt Obstet \& Gynaecol 1981;17:117-19.

[5] Borton C. Placenta and placental problems. Patient Plus 2006;20:159.

[6] Regnault TRH, Galan HL, Parker TA, et al. Placental development in normal and compromised pregnancies: a review. Placenta 2002;23(Suppl A): S119-S29.

[7] Crawford JM. A study of human placental growth with observations on the placenta in erythroblastosis foetalis. J Obstet \& Gynaecol Br Emp 1959;66:885-96.

[8] Spirt BA, Cohen WN, Weinstein HM. The incidence of placental calcification in normal pregnancies. Radiology 1982;142(3):707-11.

[9] Standring S, Ind T. Gray's Anatomy - the anatomical basis of clinical practice. Implantation, placentation, pregnancy and parturition. 39th edn. London: Churchill Livingstone 2005: p. 1341-8.

[10] Van den Broek N, Ntonya C, Kayira E, et al. Preterm birth in rural Malawi: high incidence in ultrasounddated population. Human Reproduction 2005;20(11):3235-7.
[11] Dutta AK. Essentials of human embryology. The placenta. $5^{\text {th }}$ edn. Current Books International Publishers 2005: p. 59.

[12] Janthanaphan M, Kor-Anantakul O, Geater A. Placental weight and its ratio to birth weight in normal pregnancy at Songkhlangarind hospital. J Med Assoc Thai 2006;89(2):130-7.

[13] Cross JC. The genetics of preeclampsia: a feto-placental or maternal problem? Clin Genetics 2003;64(2):96103.

[14] Machin GA, Ackerman J, Gilbert-Barness E. Abnormal umbilical cord coiling is associated with adverse perinatal outcomes. Paediatric and Developmental Pathology 2000;3(5):462-71.

[15] Jaya DS, Kumar NS, Bai LS. Anthropometric indices, cord length and placental weight in newborns. Indian Paediatric 1995;32(11):1183-8.

[16] Gupta SP, Bahl L, Dikshet SK. A study of placenta in relation to birth weight and gestational age. Indian Journal of Paediatric 1972;39(9):281-5.

[17] Frisancho AR, Matos J, Bollettino LA. Influence of growth status placental function on birth weight of infants born to young still-growing teenagers. Am J Clin Nutr 1984;40(4):801-7.

[18] Moore \& Persaud. The developing human: clinically oriented embryology. $6^{\text {th }}$ edn. 1996: p. 131-40.

[19] Bhatnagar SM, Kotari ML, Mehta LA. Essentials of human embryology. $2^{\text {nd }}$ edn. Hyderabad: Orient Longman 1983: p. 69-75.

[20] Majumdar S, Dasgupta H, Bhattacharya K. A study of placenta in normal and hypertensive pregnancies. J Anat Soc India 2005;54:1-9. 